\title{
No experimental evidence for vector-free, long-range, upstream dispersal of adult Asian clams [Corbicula fluminea (Müller, 1774)]
}

\author{
Bálint Pernecker (D) Attila Czirok • Péter Mauchart • Pál Boda (D) \\ Arnold Móra $\cdot$ Zoltán Csabai
}

Received: 10 March 2020/ Accepted: 19 December 2020/Published online: 8 January 2021

(C) The Author(s) 2021

\begin{abstract}
The Asian clam (Corbicula fluminea) is one of the rapidly spreading, very successful aquatic invasive species, which has become established widely in many parts of the world. Its spread is assumed to be by both passive and active dispersal. However, the importance of active pedal movement in dispersal is hardly known. Since there was no direct evidence of this phenomenon, field observations were combined with laboratory experiments to find out if the clams move upstream actively, and how this is
\end{abstract}

Bálint Pernecker and Attila Czirok have contributed equally to this work.

Electronic supplementary material The online version of this article (https://doi.org/10.1007/s10530-020-02446-8) contains supplementary material, which is available to authorized users.

B. Pernecker $(\bowtie) \cdot$ P. Mauchart · A. Móra · Z. Csabai Department of Hydrobiology, Institute of Biology, Faculty of Sciences, University of Pécs, Pécs, Hungary e-mail: perneckb@gamma.ttk.pte.hu

\section{A. Czirok}

Independent Researcher, Pécsvárad, Hungary

P. Boda

Department of Tisza River Research, Danube Research Institute, Centre for Ecological Research, Debrecen,

Hungary

Z. Csabai

Department of Botany and Zoology, Faculty of Sciences, Masaryk University, Brno, Czechia affected by the quality of the substrate, the density of the clams, and the water velocity. Field observations were conducted at a small watercourse with no waterborne transport. Experiments were done in an indoor artificial stream system, where the distances moved by adult clams were measured via digital image analysis. Substrate grain size, starting density of clams, and water velocity significantly affected clam movement. Fine grain sediment and slow flow velocity both facilitated spread, while there was no clear pattern of density-dependent dispersal. Also, we found no clear preference for either upstream or downstream movement. The maximum distance moved in the lab experiments predicts no more than $0.15 \mathrm{~km} / \mathrm{y}$ active pedal movement in an upstream direction, while our field observations detected a much faster $(0.5-11 \mathrm{~km} / \mathrm{y})$ upstream movement, which might be explained by passive dispersal, such as via human transport and ecto- or endozoochory. Overall, it seems that active movement of the species cannot read to long-distance migration.

Keywords Invasive species - Pedal movement . Artificial stream system · Laboratory experiment . Field observation 


\section{Introduction}

Biotic invasion is considered one of the top drivers of global biodiversity loss (Nentwig et al. 2018). Among aquatic invasive species many molluscs are very successful invasives. In particular, the Asian clam (Corbicula fluminea) is one of the rapidly spreading species and has become established in many parts of the world in a wide range of freshwater ecosystems (McMahon 2000). Corbicula fluminea can alter trophic and nutrient dynamics of aquatic systems (Sousa et al. 2008) and can have a negative impact on the entire native macroinvertebrate community (Schmidlin et al. 2012). It can act as an ecological engineer by leaving tons of empty shells behind after death of the animals, thus forming a thick layer of shells and creating a new microhabitat that covers the original microhabitat and renders its structure and composition uniform (Strayer and Malcom 2007; Sousa et al. 2009). The impact of macrofouling on human environments by $C$. fluminea can also be substantial (Darrigran 2002).

The native range of the Asian clam includes Southeast Asia, but it has now spread across North America, South America, and Europe (Beran 2006). In Europe, it was first recorded in 1980 (Mouthon 1981) and shortly after the opening of the Main-Danube Canal in 1992 it appeared in the Danube river system (Tittizer and Taxacher 1997), in which it has rapidly become widespread (Paunović et al. 2007). It now occurs in most aquatic systems in almost every European country (Hubenov et al. 2013) in large numbers, so its negative effect is an acute problem that will remain so in the future. The rising temperature in the coldest months and the increasing precipitation are the most important climatic variables that will facilitate expansion of the range of the species by $25-32 \%$ by 2080 (McDowell et al. 2014).

As for substrate preference, the species is usually associated with fine grain sediment, for example Schmidlin and Baur (2007) found that the clams prefer sand, although McDowell and Byers (2019) found that they have a coarser gravel preference. Generally, $C$. fluminea appears to be less tolerant of environmental stress than other freshwater bivalves, as indicated by mass mortality in extreme conditions (e.g. McDowell et al. 2017). However, the invasion success of the species is not attributed to its physiological tolerance, but mostly to its reproductive characteristics, including rapid growth, early sexual maturity, and high fecundity (McMahon 2002).

Unlike most freshwater bivalves, $C$. fluminea have nonparasitic planktonic larvae (e.g. Ackerman et al. 1994; Mackie 1991; Nichols and Black 1994). Juveniles are released to the water column in their pediveliger or straight-hinged veliger form, when the shell is completely formed and the foot is already present (Nichols and Black 1994; Sousa et al. 2008). The pediveliger stage lasts approximately 3-5 days (Kraemer and Galloway 1986) and in this stage the small (approx. $250 \mu \mathrm{m}$ ) clams can be transported by water flow (McMahon 2000). However, according to Sousa et al. (2008), these juveniles tend to attach to harder surfaces and sediment with byssal threads after their release to the water column, and become benthic within $48 \mathrm{~h}$ (King et al. 1986). Asian clams reach sexual maturity at 3-9 months of age, and the whole life span is $1-5$ years (Sousa et al. 2008). The species is referred to mostly as bivoltine, but water temperature and available food resources can greatly affect the number of annual reproduction periods (Sousa et al. 2008).

Regarding spread, both passive dispersal (using any kind of natural or anthropogenic vectors, and drifting in the water column) and active dispersal (on their own by pedal movement or jet propulsion) can be assumed. Passive dispersal of $C$. fluminea is primarily attributed to anthropogenic activities like cargo shipping (e.g. Lucy et al. 2012) or leisure craft (McMahon 2000). These processes may result in both upstream and downstream spreading. But in rivers and streams with no boat transport passive dispersal is possible only by natural mechanisms. Such mechanisms include pediveligers suspended in the water column (McMahon 2000) and juveniles attached to floating objects (Counts 1986). However, these natural passive methods can only result in downstream spread. Possible alternative natural vectors of passive two-directional dispersal are fishes and birds (Coughlan et al. 2017; Figuerola et al. 2005). Rapid spread is well noted on a European scale, where human mediated passive dispersal seems to be the main factor. But relatively fast upstream spread has been observed at smaller scales in streams in which the lack of boats and waterborne transport means that active movement may also be important. Moreover, even the persistence of this sedentary species, larvae of which can move only downstream in the current, leads to the 
phenomenon of 'drift-paradox', i.e. the observed persistence of sessile populations (Müller 1954, 1982).

Natural active movement of bivalves is hardly known (Schmidlin and Baur 2007) as it is difficult to examine in nature because of the complex and uncontrollable environment. There has therefore been only indirect evidence of this phenomenon so far. McMahon and Bogan (2001) assumed theoretically that the species is capable of pedal movement in an upstream direction. Fast colonization by $C$. fluminea via passive dispersal in natural water bodies has been described in several evidence-based studies (Kappes and Haase 2012, and see refs above), but the importance of active pedal movement supported by field observations has been reported only by Voelz et al. (1998) and Cupsa (2014).

Since there was no experimental evidence of the importance of active dispersal in the rapid upstream movement of the species so far, we examined this issue under laboratory conditions. We were looking for the answers to the following questions: (1) do the adult clams move upstream actively, and (2) does the quality of the substrate, the water velocity, or the density of the adult clams affect the distance moved? We hypothesised that pedal movement of adult clams may play a significant role in upstream dispersal of the species.

\section{Materials and methods}

Field survey

A field survey was undertaken to infer the upstream speed of movement of $C$. fluminea in natural conditions in a watercourse where no waterborne transport mechanism is present. Our aim was to gather information on the upstream rate of spread of the clams so as to put our experimental findings on adult clam movement in context. Our field observation was conducted in the Karasica stream (SW Hungary) (Fig. 1), a tributary of the Danube with a total length of $78 \mathrm{~km}$ (52 km in Hungary, $26 \mathrm{~km}$ in Croatia). The Karasica stream was chosen, because it is a frequently studied stream, and there were no $C$. fluminea clams in the entire length of the Hungarian section of the stream before 2014 , so that we were able to follow the upstream spread of the species. The flow of the stream is from north to south. Quantitative macroinvertebrate samples were taken at four sampling sites (Borjád, Pócsa, Villány, Lapáncsa) along the Hungarian section of the stream (Fig. 1). Samples were taken in 2009 at all sites, in 2010 and 2014 at Lapáncsa, in 2013 at Villány, in 2016 at Borjád, Pócsa and Villány, and in 2020 at Borjád according to the AQEM protocol, which is a multi-habitat type sampling method in which microhabitats are sampled according to their proportional coverage in the sampling reach (AQEM Consortium 2002). The samples were taken with the same technique and same effort each time. We could therefore determine the earliest years when the species could have colonised the sites as well as the first year they were confirmed at the sites. To calculate the upstream rates of spread, we assumed that the clams moved with constant velocities.

\section{Collection of experimental clams}

Specimens used for the laboratory experiments were collected from the middle section of the stream near Villány (Fig. 1c), to avoid the possibility of our spreading the species further upstream. The collections were made between 21 June and 3 September 2017 prior to each pilot and laboratory experiment. The clams were counted in the field, then placed in buckets filled with stream water and transported to the laboratory within half an hour.

\section{Pilot experiments}

Before the main lab experiments, pilot studies were conducted to define the final protocols. The pilots were carried out in the same artificial stream system as the final experiments (for details see the next section). Each pilot experiment was done once and took 2 weeks (between 21 June and 17 August 2017). We tested the influence of acclimation (Pilot 1), the effect and usability of several different substrates (Pilot 2), the manageability of different numbers of individuals (Pilot 3), the time dependence of movement (Pilot 4), and feeding with mussel nutrient (Pilot 5). The main outcomes of the pilots were the following. No difference was found in distances moved between acclimated and non-acclimated clams (Pilot 1), so in the main experiments we did not acclimate and thereby reduced the stress and precluded starvation and mortality in small holding aquaria. Based on Pilot 2 we chose two types of sediments for the main 


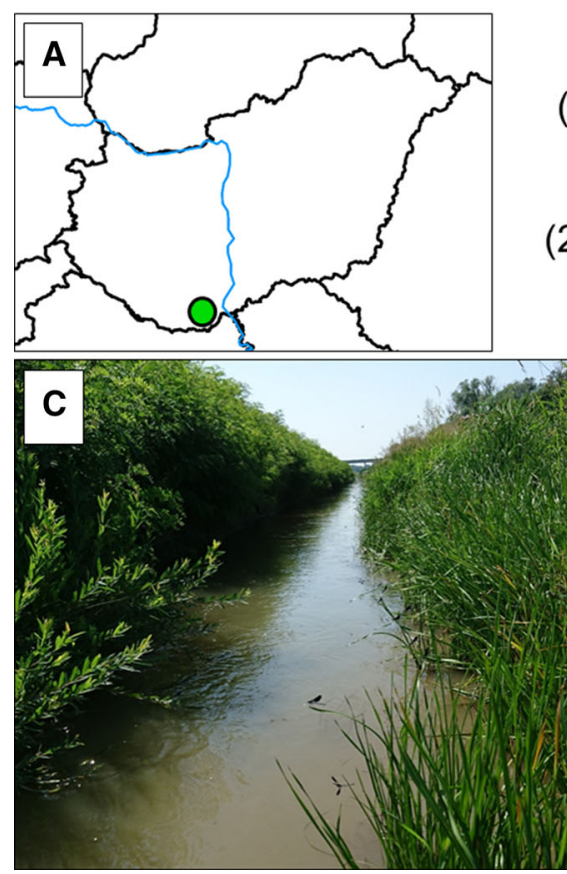

Fig. 1 The field study sites. a Map of Hungary with the location of the field survey (green dot). b The locations of the sampling sites (green dots) on the Karasica stream. Flow direction of the stream is from north to south. Black arrows indicate the direction of movement (upstream) of the clams. The years

experiment (Experiment 1, see the next section). A very fine quartz sand (grain size $0.1-0.6 \mathrm{~mm}$ ) and a coarser black basalt gravel (grain size $2-4 \mathrm{~mm}$ ) with some additional bigger (diameter 10-15 cm) stones proved to be the best substrates, because we could see the tracks of the clams more easily in these materials. Also, silt, clay, sand and gravel are the most common substrate types in the Karasica stream. To find the highest densities that were manageable with reasonable sampling and handling effort (Pilot 3), we tested extremely low to extremely high densities (5 to 2000 specimens) but did not find well defined trends in distances moved. We therefore decided to use numbers similar to the natural density in Karasica stream. Pilot 4 assessed the time to cessation of movement, with no movement occurring after $24 \mathrm{~h}$, so we set the time of exposure in the main experiment to $48 \mathrm{~h}$ to be sure that all clams has stopped moving. According to McMahon and Bogan (2001), clam movement is enhanced if there is no filterable nutrient in the water, because the species has the capability of collecting food in sediments with its extendable foot. However, we did not see differences in distances moved between

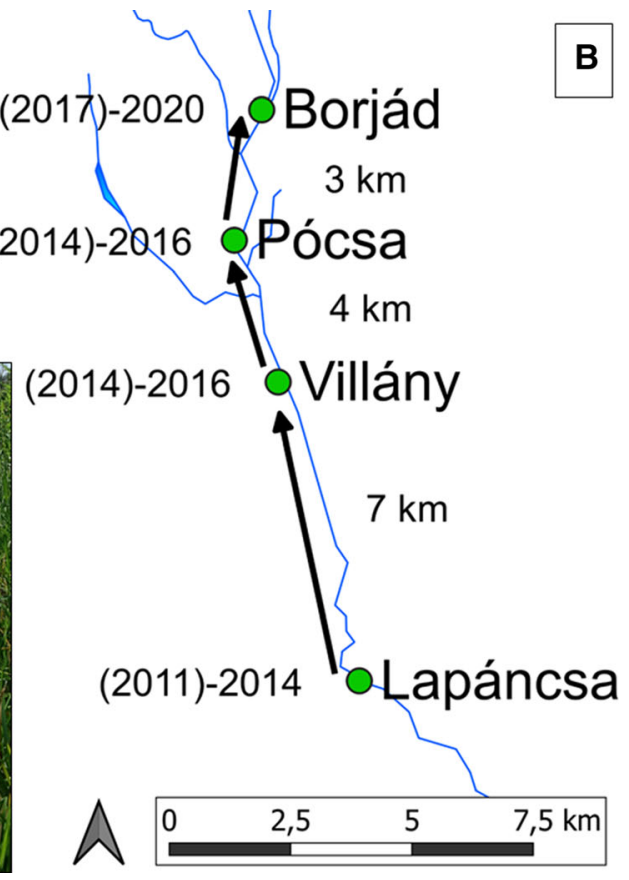

shown in parentheses are the earliest possible years when the clams could have colonised the site, and the years without parentheses are the years when clams were first collected. The distances are shown between neighbouring sample sites. $\mathbf{c}$ Photo of the sampling site at Villány

starved and fed mussels (Pilot 5), and accordingly decided not to feed the clams before or during the experiments because the exposure time was short (see Pilot 4). So, in the final protocol, clams were involved in the experiments within an hour of being collected.

\section{Laboratory experiments}

All the experiments were conducted in an indoor $2.4 \mathrm{~m}$ wide and $8.0 \mathrm{~m}$ long artificial stream system with three parallel channels. Flow was generated by twelve automated wastewater pumps, which circulated the water from the end of the system back to a buffer tank, from where the water was released into the beginning of each channel through two flexible pipes. Each channel was $0.8 \mathrm{~m}$ wide, $8.0 \mathrm{~m}$ long, and $0.4 \mathrm{~m}$ deep, located side by side. Each channel was divided into three longitudinally consecutive $1.6 \mathrm{~m}$ long experimental sections (spatial replicates): thus overall, nine replicates ran simultaneously. The details of the experimental setup of the stream system is shown in Fig. 2. Each experiment was repeated two times 


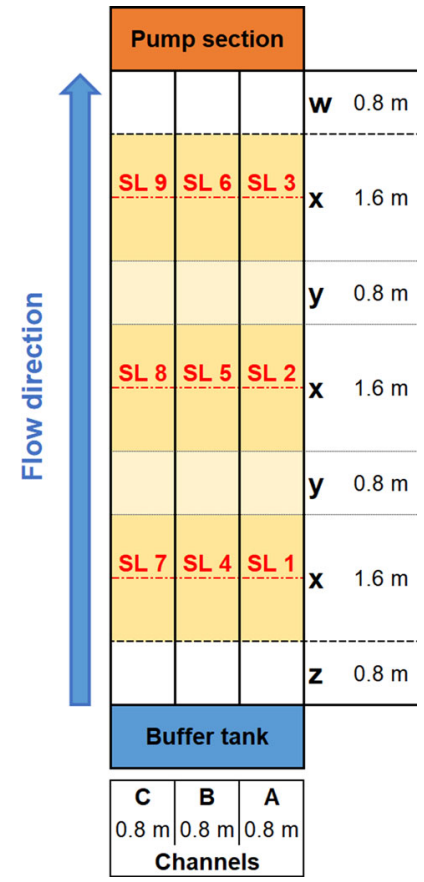

Fig. 2 Schematic layout of the artificial stream system and the experimental setup. For each experiment the system was separated into three parallel channels (channels A, B, C). Each channel was divided into three longitudinally consecutive experimental sections (spatial replicates). Red dash-dotted lines are the starting lines (SL) where the clams were placed at the beginning of each experiment. Letters indicate the different sections of the channels. w: empty section with no substrate to avoid sediment reaching the pump section (separated from the sediment-filled section by a $5 \mathrm{~cm}$ tall sill); $\mathbf{x}$ : $1.6 \mathrm{~m}$ experimental sections with the starting line in the middle; y: $0.8 \mathrm{~m}$ sections, which were sufficient that clams from one experimental section did not move so far that they entered the next experimental section (not separated, filled with sediment); $\mathbf{z}$ : empty section with no substrate to create an evenly distributed water inflow (separated from the sediment-filled section by a $5 \mathrm{~cm}$ tall sill)

(temporal replicates) between 17 August and 3 September 2017.

Each experiment took $48 \mathrm{~h}$ under standardized conditions (air temperature $22^{\circ} \mathrm{C}$, water temperature $20.6{ }^{\circ} \mathrm{C}, 10 \mathrm{D}: 14 \mathrm{~L}$ photoperiod). To provide stable and constant temperature and dissolved oxygen concentration the water was circulated for $48 \mathrm{~h}$ before each experiment. We placed $3 \mathrm{~cm}$ of sediment in each treatment to provide the substrate into which the clams could dig. At the beginning of an experiment we placed the individuals in the middle of the assigned sections of the channels (starting lines). Because of the large number of individuals that were used in the experiments, it was not possible to put all the clams side-by-side in one straight line. The clams were therefore put on the starting line as compactly as possible (Fig. 3a). No pediveliger larvae were used, only adults. All individuals were used only once, so before every experiment new individuals were collected. Specimens that had been involved once in an experiment were collected and counted after each temporal replicate, and were killed in a freezer. We could find all individuals after every experiment, and they were all in the disturbed sediment sections (see details in Image analysis), never beyond them. No clam reached the end of the sediment-filled experimental sections.

Based on the results of the pilot studies, we defined three different experiments, each with three levels of a treatment that could influence the movement of the clams. In Experiment 1 we used three sediment types. Channel A contained coarse basalt gravel (grain size 2-4 mm) with additional big stones (diameter $10-15 \mathrm{~cm}$ ), Channel B contained only basalt gravel and Channel $\mathrm{C}$ contained fine quartz sand (grain size $0.1-0.6 \mathrm{~mm}$ ). All replicates used 250 individuals and the water velocity was set to $0.05 \mathrm{~m} / \mathrm{s}$. In Experiment 2 we tested three starting densities. Replicates in Channel A used 500 individuals, in Channel B 250 individuals, and Channel C 125 individuals. All channels were filled with fine quartz sand and the water velocity was $0.05 \mathrm{~m} / \mathrm{s}$. In Experiment 3 we used three flow velocities. Water velocity in Channel A was



Fig. 3 Example of the images analysed, with the digitally fitted grid (black lines) and the measurements taken (white lines). Starting line is set horizontally. A: Initial state, B: Final state, CS: Calibration stick 
$0.07 \mathrm{~m} / \mathrm{s}$ (fast), in Channel B $0.05 \mathrm{~m} / \mathrm{s}$ (medium) and in Channel C $0.03 \mathrm{~m} / \mathrm{s}$ (slow). Fine sand and 250 individuals/replicate were used in all channels.

Image analysis

Because of the large numbers of individuals used in the experiments, it was not manageable to measure the distances moved by each clam. For the sake of comparable measurements of the distances covered, we used digital image analysis to measure the combined tracks of the clams (i.e. the disturbed sediment) as a whole. To test the movement of the specimens 21 megapixel resolution digital images of the replicates were taken from above at the beginning (Fig. 3a) and the end (Fig. 3b) of each experiment. We measured the total distances covered by the clams along a digitally fitted grid of 12 equally spaced parallel lines (perpendicular to the starting line, Fig. 3 black lines), from which the two lines next to the walls were omitted to reduce the influence of any edge effect. Along each of the remaining 10 parallel lines we measured the distances from the starting line to the farthest points reached by the clams (i.e. the disturbed sediment, Fig. 3 white lines) both upstream and downstream after the $48 \mathrm{~h}$ experiment. Because of the large number of individuals that were used in the experiments, the clams had an initial extent in both upstream and downstream directions from the starting line. This initial value was also measured (Fig. 3a white lines). The movements of the clams were determined by subtracting the initial from the final values (Fig. 3b white lines). All measurements were made in the GNU Image Manipulation Program (GIMP) ver. 2.8.22 (The GIMP Development Team 2017), in which the distances were given in pixels. Using a one-meter-long calibration stick, which was put in the channels only when the images were taken, the movement could be calculated in $\mathrm{cm}$.

Statistical analysis

Two types of general mixed models were created.

Type I Three general mixed models (one for each Experiment) were created to reveal the effects of the treatments on the total distances moved by the clams. Dependent variables were the total measured distances moved by the clams in each Experiment.
Treatments (Channel A, B, C for each Experiment, for more details see Laboratory experiments) were treated as fixed-effects. The spatial and temporal replicates were set as random-effects. To reveal the significant differences among the three treatments, three post hoc pairwise comparison analyses (one for each Experiment) were also done based on the general mixed models by computing and comparing the estimated marginal means of the treatments, using the Tukey method, with degrees-of-freedom using the Kenward-Rogers method).

Type II To reveal the differences between the distances moved in upstream and downstream directions, nine more general mixed models were developed (one for each treatment). Dependent variables were the distances moved by the clams in separate upstream and downstream directions in each treatment. The direction of movement (up or down) were fixed-effects, while the spatial and temporal replicates were set as random-effects.

The general mixed models result in fixed effects coefficients, which show the magnitude and direction of the effects compared to the reference categories (which was 'Channel A' for Type I, and 'Direction Down' for Type II models). The mixed models were created in RStudio Desktop 1.3.1056 (R Core Team 2020) using the package lme4 (Bates et al. 2015). The pairwise comparisons were made using the package emmeans (Lenth 2020).

\section{Results}

Field survey

The species was found for the first time in the Karasica stream in 2014 at the southernmost site at Lapáncsa (93 ind. $/ \mathrm{m}^{2}$ ) $35 \mathrm{~km}$ upstream from the stream's influx to the Danube. According to the results of the Joint Danube Survey 1, C. fluminea was present in this section of the Danube in 2001 in 'low density' (Bernerth et al. 2002). After that, it was detected at Villány (920 ind. $/ \mathrm{m}^{2}$ ) and Pócsa $\left(50\right.$ ind. $\left./ \mathrm{m}^{2}\right)$ in 2016 , when it was very abundant $\left(2700\right.$ ind. $\left./ \mathrm{m}^{2}\right)$ at Lapáncsa. It was first found at the most upstream site at Borjád in early 2020 in low abundance $\left(6\right.$ ind. $\left./ \mathrm{m}^{2}\right)$. However, C. fluminea was absent from Lapáncsa in 2010, also absent from Villány in 2013, and no 
specimens were detected at Borjád in 2016. This means that the species could have appeared between 2011 and 2014 at Lapáncsa, between 2014 and 2016 at Villány and Pócsa, and between 2017 and 2020 at Borjád (Fig. 1b). So far, despite the efforts of several thorough surveys, no $C$. fluminea specimens have been collected upstream of Borjád. So, it took the species 1-6 years to cover the $11 \mathrm{~km}$ between Lapáncsa and Pócsa, which indicates a $1.8-11 \mathrm{~km} / \mathrm{y}(4.9-30.1 \mathrm{~m} / \mathrm{d})$ upstream dispersal speed, and 2-6 years to reach Borjád from Pócsa, a distance of $3 \mathrm{~km}$, which results in a $0.5-1.5 \mathrm{~km} / \mathrm{y}(1.4-8.2 \mathrm{~m} / \mathrm{d})$ upstream movement speed. The average speed of dispersal from the Danube to Borjád $(49 \mathrm{~km})$ was $2.5-2.9 \mathrm{~km} / \mathrm{y}$.

\section{Laboratory experiments}

\section{Experiment 1: Different substrates}

The Type I general mixed model showed that the treatment (sediment type) had a significant effect on the distances moved (Table S1). The fixed effects coefficients differed significantly among treatments and the pairwise comparisons showed significant differences between all treatment pairs (Channel A$\mathrm{B}: \quad$ estimate $=-5.65, \quad \mathrm{SE}=2.36, \quad \mathrm{df}=174$, $p=0.046$; Channel A-C: estimate $=-39.98, \mathrm{SE}=$ 2.36, df $=174, \quad p<0.001$; Channel B-C: estimate $=-34.33, \mathrm{SE}=2.36, \mathrm{df}=174, \quad p<0.001$ ) (Fig. 4a, Table S1). Individuals on the fine quartz sand sediment covered significantly more distance than the ones on the coarser sediment types (Fig. 4a). Based on this result, fine quartz sand was selected as substrate for Experiments 2 and 3. Based on the Type II general mixed models, a significant difference between the extent of upstream and downstream movement was found only in the coarse basalt gravel with stones (Direction Up: $-4.743, \mathrm{SE}=1.339$, $p<0.001$ ) (Fig. 4b, Table S2). The downstream direction was preferred by the clams in all three cases (Table S3).

\section{Experiment 2: Different starting densities}

Starting density had a significant effect on movement distances (Table S1). The fixed effects coefficient of the Type I general mixed model differed significantly among treatments and the pairwise comparisons showed significant differences between all treatment pairs $($ Channel A-B: estimate $=34.50, \mathrm{SE}=2.83$, df $=174, p<0.001 ;$ Channel A-C: estimate $=19.50$, $\mathrm{SE}=2.83$, df $=174, p<0.001$; Channel B-C: estimate $=-15.00, \mathrm{SE}=2.83, \mathrm{df}=174, \quad p<0.001$ ) (Fig. 4c, Table S1). However, no clear pattern was found, as the biggest distance moved was in the highest density treatment, while the lowest occurred in the medium density treatment (Fig. 4c). Significant differences were also found by the Type II general mixed model in the high density treatment (Direction Up: 6.139, $\mathrm{SE}=2.263, p<0.01$ ) and low density treatment (Direction Up: $-6.008, \mathrm{SE}=2.318$, $p<0.01$ ) but not for the medium density treatment (Direction Up: $-1.453, \quad \mathrm{SE}=1.192, \quad p>0.05$ ) (Fig. 4d, Table S2). Upstream movement was preferred in the high density treatment, and downstream movement was preferred in the low density treatment (Table S3).

\section{Experiment 3: Different water flow velocities}

The Type I general mixed model showed that water velocity had a significant effect on the distances moved (Table S1). The fixed effects coefficient differed significantly among treatments and the pairwise comparisons showed significant differences only between fast and slow flow (Channel A-C: estimate $=-19.70, \mathrm{SE}=2.76, \mathrm{df}=174, \quad p<0.001)$ and medium and slow flow (Channel B-C: estimate $=-13.43, \mathrm{SE}=2.76, \mathrm{df}=174, p<0.001$ ), but no significant difference between fast and medium flow (Channel A-B: estimate $=-6.27, \mathrm{SE}=2.76$, df $=174, p=0.062)$ (Fig. 4e, Table S1). The distances moved by the clams were significantly greater in slow flow compared to fast and medium flow treatments (Fig. 4e). Based on the Type II general mixed model the clams moved greater distances upstream than downstream in all cases (Table S3), and these differences were significant in the fast flow (Direction Up: 4.107, SE $=1.920, p<0.05$ ) and the medium flow (Direction Up: 6.542, SE $=1.390$, $p<0.001$ ) (Fig. 4f, Table S2).

\section{Discussion}

The influence of $C$. fluminea on aquatic ecosystems is inconsistent (see Introduction), but as a non-indigenous species, disentangling the processes behind its 


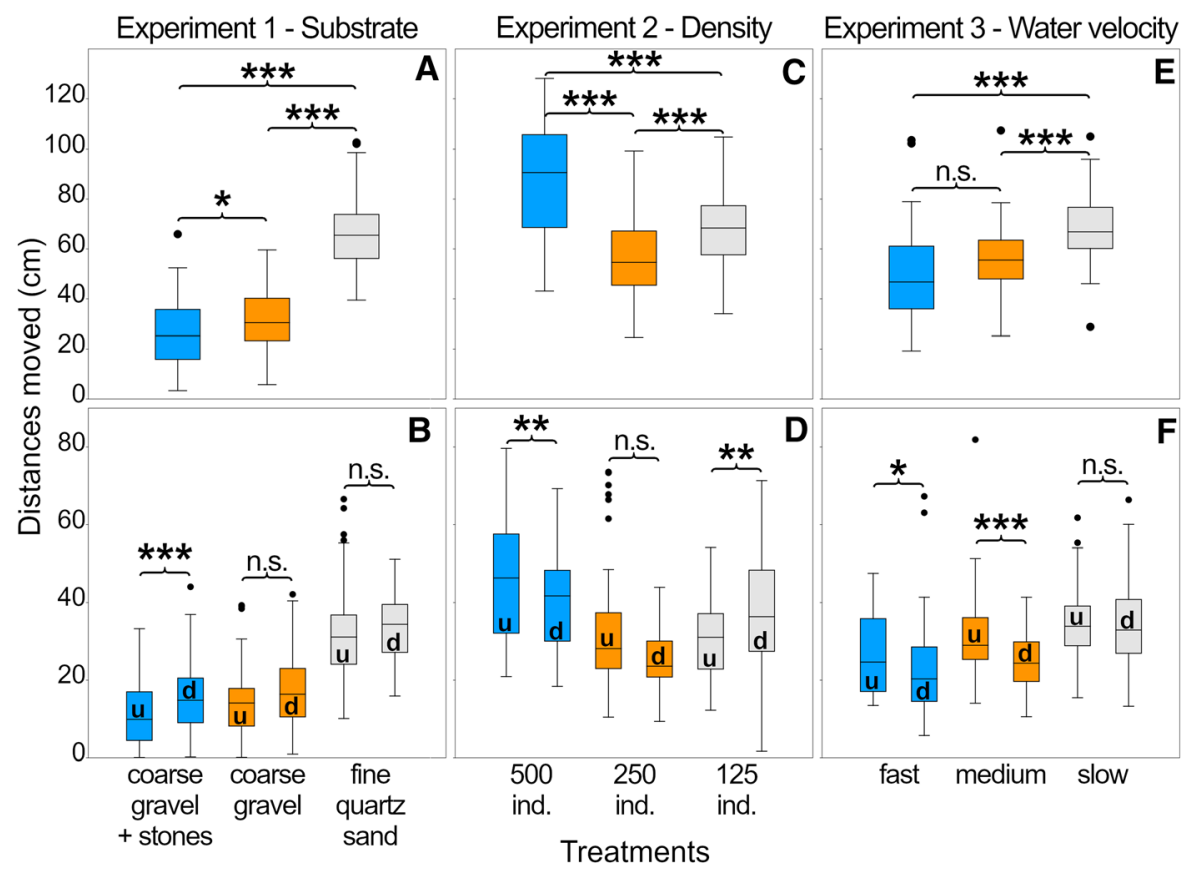

Fig. 4 Total distances moved (top row: A, C, E) and separate upstream and downstream distances moved (bottom row: B, D, F) by the clams in each experiment ( $\square$ : interquartile range, - : median, $\top$ : minimum and maximum values without outliers,

dispersal is important from both ecological and nature conservation perspectives.

Natural spread is generally associated with downstream passive dispersal in the water current (Prezant and Chalermwat 1984). Upstream active dispersal can also be a common behaviour and it is often predominant among aquatic invertebrates (e.g. Elliott 2003). Although we observed both upstream and downstream dispersal in our experiments, no clear pattern was observed in dispersal direction preference.

The greatest distance moved was on the fine quartz sand substrate, which suggests that the fine grained sediment provides more appropriate environment for Asian clams to move and this substrate type may facilitate the dispersal of the species. Similarly, observations and field experiments showed that $C$. fluminea prefers fine grained sediment in natural conditions (Schmidlin and Baur 2007).

The grain size generally depends on the water current, and their effects often cannot be separated (Schmidlin and Baur 2007). However, in our study there were differences among distances moved by clams in different velocity conditions but on the same substrate. This suggests that current velocity can outlier, u: upstream, d: downstream, n.s.: not significant, $* p<0.05, * * p<0.01, * * * p<0.001$, for the supporting statistical analyses see Tables S1 and S2)

influence the dispersal of clams independently of substrate type. Water velocity negatively affects active dispersal of many bivalve species (Kappes and Haase 2012), and our results confirm this observation in the case of $C$. fluminea. Accordingly, this species seems likely to be less successful in colonizing rivers with rapid currents, not only because of the reduced amount of available food (e.g. phytoplankton) (Schmidlin and Baur 2007) but also because of the effect of rapid water velocity itself.

Density-dependent dispersal is well known in terrestrial animals (e.g. Bengtsson et al. 1994; Matthysen 2005) and marine invertebrates (e.g. Byers 2000 and refs therein), but seems less characteristic in freshwater aquatic macroinvertebrates (e.g. Elliott 2003; Koetsier and Bryan 1996). Our results suggest that the dispersal activity (i.e. distance moved) of $C$. fluminea is somewhat density-dependent, but the processes behind this are not yet clear (i.e. the distance moved was the shortest in the medium density treatment and greater in both the high and low density treatments). In a former study (Elliott 2003) no differences were found between upstream and downstream movement of aquatic invertebrates in relation 
to density. In contrast, we found that $C$. fluminea preferred upstream dispersal in the high density treatments and downstream dispersal in the low density treatment. To our knowledge this is the first evidence for density-dependent preference of a freshwater bivalve species for direction of dispersal in relation to water flow.

All in all, these parameters may affect the movement of Asian clams, but only on a very small scale. In our experiments, the average distance moved upstream in $48 \mathrm{~h}$ was $28.96 \mathrm{~cm}$ (min: $0 \mathrm{~cm}$, max: $81.88 \mathrm{~cm}$ ), while downstream it was $27.83 \mathrm{~cm}$ (min: $0 \mathrm{~cm}$, max: $71.33 \mathrm{~cm}$ ), with the upstream value predicting no more than $150 \mathrm{~m}$ self-movement upstream in a year. Our long-term field observations found a much faster (ca. $0.5-11 \mathrm{~km} /$ year) upstream spread of the species in Karasica stream. However, based on the abundances of the species at the sampling sites, which was quite high (93 ind. $/ \mathrm{m}^{2}$ ) at Lapáncsa in 2014, but increased to extremely high $\left(2700 \mathrm{ind} . / \mathrm{m}^{2}\right)$ in 2016, and which was also very high $\left(920 \mathrm{ind} . / \mathrm{m}^{2}\right)$ at Villány, but relatively lower $\left(50\right.$ ind. $/ \mathrm{m}^{2}$ ) at Pócsa in 2016, and very low $\left(6\right.$ ind. $\left./ \mathrm{m}^{2}\right)$ at Borjád in early 2020 , the most probable scenario is the following. The species might have established at Lapáncsa in 2012-2013, then reached Villány in 2014-2015, Pócsa in 2015-2016, and finally it might have reached Borjád in 2018-2019. In this case the speed of movement would have been $1.4-7 \mathrm{~km} / \mathrm{y}$ for the $7 \mathrm{~km}$ between Lapáncsa and Villány, 2-4 km/y for the $4 \mathrm{~km}$ between Villány and Pócsa, and $0.75-1.5 \mathrm{~km} / \mathrm{y}$ between Pócsa and Borjád. This is close to the $1.2 \mathrm{~km} /$ year upstream movement speed in a small southeastern U.S. blackwater stream (Voelz et al. 1998), and the $2.5-2.9 \mathrm{~km} / \mathrm{y}$ average movement speed from the estuary of the Karasica to Borjád is also similar to the $2.4 \mathrm{~km} /$ year reported by Schmidlin and Baur (2007) in the upper Rhine, where no inland navigation takes place. However, there is always a slight chance that field observations are overestimating the speed of movement of the clams. Uncertainties could arise from the facts that samples were not taken every year at every site, and because there might be a time lag between the real arrival and the first detection of a non-indigenous species as the likelihood of detection of a small, early-stage population is also low (Leuven et al. 2009). Nonetheless, the application of the same sampling method and effort (AQEM protocol) throughout our study is likely to reduce the error of dispersal rate estimation, because the time lag between arrival and detection may be similar at each site. Similarly, because of the artificially created environment, which represents only a small range of abiotic factors, there is a possibility that the laboratory studies underestimated the speed of dispersal of the clams. However, even the slowest estimated speed in the Karasica stream $(0.5 \mathrm{~km} / \mathrm{y}$ between Pócsa and Borjád) is almost four times faster than what was measured in the lab.

Based on our results, for long-range upstream spread the species needs some kind of vector. Although there is no waterborne transport on the Karasica stream, human influence can not be excluded, because fishermen sometimes use $C$. $f l u$ minea as bait (Schmidlin and Baur 2007), and it is also possible that individuals are transported on fishing equipment or stuck into boots or waders (anthropochory). Moreover, ecto- or endozoochory are also possible explanations for the fast upstream migration of the species. Young individuals or small propagules are more suited to ectozoochory (Figuerola and Green 2002). In the case of small $(<2.5 \mathrm{~mm})$ juveniles of three pond snails Boag (1986) reported waterfowlmediated transport through attachment to feathers. Juvenile Asian clams are small (approx. $250 \mu \mathrm{m}$ ), and have mucilaginous byssal threads, which they use to attach to hard surfaces, but they can be re-suspended in the water later (McMahon 2000). Also, if they attach to filamentous algae, they can be transported accidentally by waterbirds (McMahon 1982). Aquatic invertebrates like crayfish, reptiles, and semi-aquatic mammals like otters and beavers can play a role in dispersing aquatic invertebrates (Banha and Anastáció 2012; Waterkeyn et al. 2010). Also, terrestrial mammals like deers or wild boars that visit surface waters regularly are possible vectors, as some aquatic invertebrates can attach to their fur and can be transported to other locations (Banha and Anastácio 2012). On the other hand, spread of $C$. fluminea as juveniles attached to birds' feathers or legs is accidental (Thompson and Sparks 1977), and because of the high body temperature of birds, dispersal in waterfowl guts is also unlikely (Gatlin et al. 2013). Moreover, unlike the glochidial larvae of unionid bivalves, larvae of Corbicula species are not adapted to attaching externally to fish (McMahon 2002). More recently an experimental study found that more than $20 \%$ of the individuals may survive getting through the digestive 
system of blue catfish (Ictalurus furcatus) (Gatlin et al. 2013). However, the introduction of only one specimen can be enough to start a new population, because the species is hermaphroditic and able to cross- and self-fertilize, which may result in more than 68000 pediveligers/adult/year (McMahon 2000).

Overall, it seems that large adult $C$. fluminea are able to spread somewhat without any vector, but this kind of dispersal is much less significant than expected. The maximum distance that the clams were capable of moving was around $0.7-0.8 \mathrm{~m}$ in 2 days, but most of this distance was covered in the first $24 \mathrm{~h}$. This kind of pedal movement seems to be much more suitable for the clams to move to optimal microhabitats (based on, for example, the quantity or quality of nutrients, water current, density, substrate, etc.) in a section where they were previously introduced, but it is not feasible for long-distance dispersal. In addition, C. fluminea possesses all three attributes (spawning over multiple seasons, short pelagic life phase, high reproductive rate) that can help a sessile organism with pelagic larvae to remain in place or spread upstream (Byers and Pringle 2006). Therefore it is also possible that active upstream movement of $C$. fluminea is a behaviour to compensate for downstream drifting to some extent (Humphries and Ruxton 2002).

To conclude, we found no experimental evidence for fast, long-distance, active dispersal of adult Asian clams. The very fast upstream invasion in Karasica stream might be explained by passive dispersal that was not investigated in our experiment, e.g. via ectoor endozoochory. Based on our results, in order to develop successful methods and management plans to control the spread of this non-indigenous invasive species in stream environments, researchers and stakeholders should focus on processes that can result in passive long-distance dispersal of the clams.

Acknowledgements The authors express their gratitude to Gábor Várbíró (Centre for Ecological Research) for his help with the general mixed models. ZC, AM, PM and BP were supported by the Higher Education Institutional Excellence Programme of the Ministry of Human Capacities in Hungary, within the framework of the 20765-3/2018/FEKUTSTRAT and TUDFO/47138/2019-ITM "Innovation for sustainable and healthy living and environment" thematic programme of the University of Pécs. BP and PM were supported by EU-funded project no. EFOP-3.6.1.-16-2016-00004.

Funding Open Access funding provided by University of Pécs. ZC, AM, PM and BP were supported by the Higher
Education Institutional Excellence Programme of the Ministry of Human Capacities of Hungary, within the framework of the 20765-3/2018/FEKUTSTRAT and TUDFO/47138/2019-ITM "Innovation for sustainable and healthy living and environment" thematic programme of the University of Pécs. BP and PM were supported by EU-funded project no. EFOP3.6.1.-16-2016-00004 through the Ministry of Human Capacities of Hungary.

Data availability The data that support the findings of this study are available from the corresponding author upon reasonable request.

\section{Compliance with ethical standards}

Conflict of interest The authors declare that there are no conflicts of interest that could be perceived as prejudicing the impartiality of the research reported.

Human and animal rights The study did not involve any kind of endangered or protected species. No specific scientific research permits were required for the collection, transporting, maintaining of these highly invasive invertebrates. Because the releasing of non-indigenous invasive species to natural habitats is forbidden by law in Hungary (Law No. LIII of 1996 on Nature Conservation, Regulation EU No 1143/2014 2014) the killing of the specimens were done as humanely and painlessly as possible in compliance with the Guidelines for the treatment of animals in behavioural research and teaching (2020).

Open Access This article is licensed under a Creative Commons Attribution 4.0 International License, which permits use, sharing, adaptation, distribution and reproduction in any medium or format, as long as you give appropriate credit to the original author(s) and the source, provide a link to the Creative Commons licence, and indicate if changes were made. The images or other third party material in this article are included in the article's Creative Commons licence, unless indicated otherwise in a credit line to the material. If material is not included in the article's Creative Commons licence and your intended use is not permitted by statutory regulation or exceeds the permitted use, you will need to obtain permission directly from the copyright holder. To view a copy of this licence, visit http://creativecommons.org/licenses/by/4.0/.

\section{References}

Ackerman JD, Sim B, Nichols SJ (1994) A review of the early life history of zebra mussels (Dreissena polymorpha): comparisons with marine bivalves. Can J Zool 72:1169-1179

Banha F, Anastácio PM (2012) Waterbird-mediated passive dispersal of river shrimp Athyaephyra desmaresti. Hydrobiologia 694:197-204. https://doi.org/10.1007/s10750012-1160-7 
Bates D, Maechler M, Bolker B, Walker S (2015) Fitting linear mixed-effects models using lme4. J Stat Softw 67:1-48. https://doi.org/10.18637/jss.v067.i01

Bengtsson G, Hedlund K, Rundgren S (1994) Food- and densitydependent dispersal: evidence from a soil collembolan. J Anim Ecol 63:513-520

Beran L (2006) Spreading expansion of Corbicula fluminea (Mollusca: Bivalvia) in the Czech Republic. Heldia 6:187-192

Bernerth H, Tobias W, Stein S Turowski S (2002) Chapter 4.2 Macrozoobenthos. In: Literáthy $\mathrm{P}$, Koller-Kreimel V, Liska I (eds) Joint Danube survey-technical report of the international commission for the protection of the Danube River, pp 32-64. https://www.icpdr.org/main/activitiesprojects/joint-danube-survey-1

Boag DA (1986) Dispersal in pond snails: potential role of waterfowl. Can J Zool 64:904-909. https://doi.org/10. 1139/z86-136

Byers JE (2000) Effects of body size and resource availability on dispersal in a native and a non-native estuarine snail. J Exp Mar Biol Ecol 248:133-150. https://doi.org/10.1016/ S0022-0981(00)00163-5

Byers JE, Pringle JM (2006) Going against the flow: Retention, range limits and invasions in advective environments. Mar Ecol Prog Ser 313:27-41. https://doi.org/10.3354/ meps313027

AQEM Consortium (2002) Manual for the application of the AQEM system. A comprehensive method to assess European streams using benthic macroinvertebrates, developed for the purpose of the Water Framework Directive. Version 1.0, February 2002

Coughlan NE, Stevens AL, Kelly TC, Dick JTA, Jansen MAK (2017) Zoochorous dispersal of freshwater bivalves: an overlooked vector in biological invasions? Knowl Manag Aquat Ecosyst 418:42. https://doi.org/10.1051/kmae/ 2017037

Counts CL (1986) The zoogeography and history of the invasion of the United States by Corbicula fluminea (Bivalvia: Corbiculidae). In: Britton JC (ed), Proceedings of the second international corbicula symposium. American Malacological Union, Special Edition, pp 7-39

Cupsa D (2014) Corbicula fluminea upstream expansion in Crisuri rivers, Tisa hydrographical basin (Hungarian-Romanian cross-border). North West J Zool 10:438-440

Darrigran G (2002) Potential impact of filter-feeding invaders on temperate inland freshwater environments. Biol Invasions 4:145-156

Elliott JM (2003) A comparative study of the dispersal of 10 species of stream invertebrates. Freshw Biol 48:1652-1668

Figuerola J, Green AJ (2002) Dispersal of aquatic organisms by waterbirds: a review of past research and priorities for future studies. Freshw Biol 47:483-494. https://doi.org/10. 1046/j.1365-2427.2002.00829.x

Figuerola J, Green AJ, Michot TC (2005) Invertebrate eggs can fly: evidence of waterfowl-mediated gene flow in aquatic invertebrates. Am Nat 165:274-280. https://doi.org/10. 2307/3473151

Gatlin MR, Shoup DE, Long JM (2013) Invasive zebra mussels (Driessena [sic!] polymorpha) and Asian clams (Corbicula fluminea) survive gut passage of migratory fish species: implications for dispersal. Biol Invasions 15:1195-1200. https://doi.org/10.1007/s10530-012-0372-0

Guidelines for the treatment of animals in behavioural research and teaching (2020) Animal behaviour, vol. 159, pp I-XI, ISSN 0003-3472, https://doi.org/10.1016/ j.anbehav.2019.11.002

Hubenov Z, Trichkova T, Kenderov L, Kozuharov D (2013) Distribution of Corbicula fluminea (Mollusca: Corbiculidae) over an eleven-year period of its invasion in Bulgaria. Acta Zool Bulg 65:315-326

Humphries D, Ruxton GD (2002) Is there really a drift paradox? J Anim Ecol 71:151-154. https://doi.org/10.1046/j.00218790.2001.00579.x

Kappes H, Haase P (2012) Slow, but steady: dispersal of freshwater molluscs. Aquat Sci 74:1-14. https://doi.org/10. 1007/s00027-011-0187-6

King CA, Langdon CJ, Counts CL III (1986) Spawning and early development of Corbicula fluminea (Bivalvia: Corbiculidae) in laboratory culture. Am Malacol Bull 4:81-88

Koetsier P, Bryan CF (1996) Is macroinvertebrate drift a density-dependent mechanism of the benthos in the Lower Mississippi River? J Freshw Ecol 11:1-10

Kraemer LR, Galloway ML (1986) Larval development of Corbicula fluminea (Müller) (Bivalvia: Corbiculacea): an appraisal of its heterochrony. Am Malacol Bull 4:71-79

Lenth R (2020) Emmeans: estimated marginal means, aka Least-Squares Means. R package version 1.5.1. https:// CRAN.R-project.org/package $=$ emmeans

Leuven RSEW, van der Velde G, Baijens I, Snijders J, van der Zwart C, Lenders HJR, Bij de Vaate A (2009) The river Rhine: a global highway for dispersal of aquatic invasive species. Biol Invasions 11:1989-2008. https://doi.org/10. 1007/s10530-009-9491-7

Law No. LIII of 1996 on Nature Conservation. [1996. évi LIII. törvény a természet védelméröl-In Hungarian] http:// www.fao.org/faolex/results/details/en/c/LEXFAOC011619

Lucy FE, Karatayev AY, Burlakova LE (2012) Predictions for the spread, population density, and impacts of Corbicula fluminea in Ireland. Aquat Invasions 7:465-474. https:// doi.org/10.3391/ai.2012.7.4.003

Mackie GL (1991) Biology of the exotic zebra mussel, Dreissena polymorpha, in relation to native bivalves and its potential impact in Lake St. Clair. In: Munawar M, Edsall T (eds) Environmental assessment and habitat evaluation of the upper Great Lakes connecting channels. Hydrobiologia vol 219, pp 251-268

Matthysen E (2005) Density-dependent dispersal in birds and mammals. Ecography 28:403-416

McDowell WG, Byers JE (2019) High abundance of an invasive species gives it an outsized ecological role. Freshw Biol 64:577-586. https://doi.org/10.1111/fwb.13243

McDowell WG, Benson AJ, Byers JE (2014) Climate controls the distribution of a widespread invasive species: implications for future range expansion. Freshw Biol 59:847-857. https://doi.org/10.1111/fwb.12308

McDowell WG, McDowell WH, Byers JE (2017) Mass mortality of a dominant invasive species in response to an extreme climate event: implications for ecosystem function. Limnol Oceanogr 62:177-188. https://doi.org/10. 1002/lno.10384 
McMahon RF (1982) The occurrence and spread of the introduced Asiatic freshwater clam, Corbicula fluminea (Müller), in North America: 1924-1982. Nautilus 96:134-141

McMahon RF (2000) Invasive characteristics of the freshwater bivalve Corbicula fluminea. In: Claudi R, Leach JH (eds) Nonindigenous Freshwater Organisms: Vectors, Biology, and Impacts. Lewis Publishers, Boca Raton, pp 315-343

McMahon RF (2002) Evolutionary and physiological adaptations of aquatic invasive animals: $r$ selection versus resistance. Can J Fish Aquat Sci 59:1235-1244

McMahon RF, Bogan AE (2001) Mollusca: Bivalvia. In: Thorp JH, Covich AP (eds) Ecology and Classification of North American Freshwater Invertebrates, 2nd edn. Academic Press, San Diego, pp 331-429

Mouthon J (1981) Sur la présence en France et au Portugal de Corbicula (Bivalvia, Corbiculidae) originaire d'Asie. Basteria 45:109-116

Müller K (1954) Investigations on the organic drift in North Swedish streams. Institute Of Freshwater Research, Drottningholm, Report 34:133-148

Müller K (1982) The colonization cycle of freshwater insects. Oecologia 53:202-207

Nentwig W, Bacher S, Kumschick S, Pyšek P, Vilà M (2018) More than "100 worst" alien species in Europe. Biol Invasions 20:1611-1621. https://doi.org/10.1007/s10530017-1651-6

Nichols SJ, Black MG (1994) Identification of larvae: the zebra mussel (Dreissena polymorpha), quagga mussel (Dreissena rosteriformis bugensis), and Asian clam (Corbicula fluminea). Can J Zool 72:406-417. https://doi.org/10.1139/ z94-057

Paunović M, Csányi B, Knežević S, Simić V, Nenadić D, Jakovčev-Todorović D, Stojanović B, Cakić P (2007) Distribution of Asian clams Corbicula fluminea (Müller, 1774) and C. fluminalis (Müller, 1774) in Serbia. Aquat Invasions 2:99-106. https://doi.org/10.3391/ai.2007.2.2.3

Prezant RS, Chalermwat K (1984) Flotation of the bivalve Corbicula fluminea as a means of dispersal. Science 225:1491-1493. https://doi.org/10.1126/science.225.4669. 1491

Regulation (EU) No 1143/2014 of the European Parliament and of the Council of 22 October 2014 on the prevention and management of the introduction and spread of invasive alien species. http://data.europa.eu/eli/reg/2014/1143/oj

Schmidlin S, Baur B (2007) Distribution and substrate preference of the invasive clam Corbicula fluminea in the river
Rhine in the region of Basel (Switzerland, Germany, France). Aquat Sci 69:153-161. https://doi.org/10.1007/ s00027-006-0865-y

Schmidlin S, Schmera D, Baur B (2012) Alien molluscs affect the composition and diversity of native macroinvertebrates in a sandy flat of Lake Neuchâtel, Switzerland. Hydrobiologia 679:233-249. https://doi.org/10.1007/s10750-0110889-8

Sousa R, Antunes C, Guilhermino L (2008) Ecology of the invasive Asian clam Corbicula fluminea (Müller, 1774) in aquatic ecosystems: an overview. Ann Limnol 44:85-94. https://doi.org/10.1051/limn:2008017

Sousa R, Gutiérrez JL, Aldridge DC (2009) Non-indigenous invasive bivalves as ecosystem engineers. Biol Invasions 11:2367-2385. https://doi.org/10.1007/s10530-009-94227

Strayer DL, Malcom HM (2007) Shell decay rates of native and alien freshwater bivalves and implications for habitat engineering. Freshw Biol 52:1611-1617. https://doi.org/ 10.1111/j.1365-2427.2007.01792.x

R Core Team (2020) R: a language and environment for statistical computing. R Foundation for Statistical Computing, Vienna, Austria. https://www.R-project.org/

The GIMP Development Team (2017) GIMP 2.8.22. https:// www.gimp.org. Accessed 17 July 2018

Thompson CM, Sparks RE (1977) Improbability of dispersal of adult Asiatic clams, Corbicula manilensis, via the intestinal tract of migratory waterfowl. Am Midl Nat 98:219-223

Tittizer T, Taxacher M (1997) Erstnachweis von Corbicula fluminealfluminalis (Müller 1774) (Corbiculidae, Mollusca) in der Donau. Lauterbornia 31:103-107

Voelz NJ, McArthur JV, Rader RB (1998) Upstream mobility of the asiatic clam Corbicula fluminea: identifying potential dispersal agents. J Freshw Ecol 13:39-45. https://doi.org/ 10.1080/02705060.1998.9663589

Waterkeyn A, Pineau O, Grillas P, Brendonck L (2010) Invertebrate dispersal by aquatic mammals: a case study with nutria Myocastor coypus (Rodentia, Mammalia) in Southern France. Hydrobiologia 654:267-271. https://doi. org/10.1007/s10750-010-0388-3

Publisher's Note Springer Nature remains neutral with regard to jurisdictional claims in published maps and institutional affiliations. 